\title{
Holocene sea-level rise evidenced in Hells Bells 234U/238U ratio and geochemical composition
}

\author{
Nils Schorndorf ( $\square$ nils.schorndorf@iup.uni-heidelberg.de ) \\ Heidelberg University https://orcid.org/0000-0003-0043-061X
}

Norbert Frank

Heidelberg University

Simon Ritter

Heidelberg University

\section{Sophie Warken}

Heidelberg University https://orcid.org/0000-0003-3293-9074

\section{Christian Scholz}

Heidelberg University

\section{Frank Keppler}

Heidelberg University https://orcid.org/0000-0003-2766-8812

\section{Denis Scholz}

University of Mainz https://orcid.org/0000-0002-0055-8915

\section{Michael Weber}

University of Mainz https://orcid.org/0000-0002-9086-9345

Jeronimo Aviles Olguin

Instituto de la Prehistoria de América

wolfgang stinnesbeck

Heidelberg University

\section{Article}

Keywords:

Posted Date: February 10th, 2022

DOI: https://doi.org/10.21203/rs.3.rs-1272536/v1

License: (9) This work is licensed under a Creative Commons Attribution 4.0 International License. Read Full License 

${ }^{234} \mathrm{U} /{ }^{238} \mathrm{U}$ ratio and geochemical composition

Nils Schorndorf ${ }^{1,2}$, Norbert Frank ${ }^{2,1,3}$, Simon M. Ritter ${ }^{1}$, Sophie F. Warken ${ }^{1,2}$, Christian Scholz ${ }^{1}$, Frank Keppler ${ }^{1,3}$, Denis Scholz ${ }^{4}$, Michael Weber ${ }^{4}$, Jeronimo Aviles Olguin ${ }^{5,6}$, Wolfgang Stinnesbeck ${ }^{1,3}$

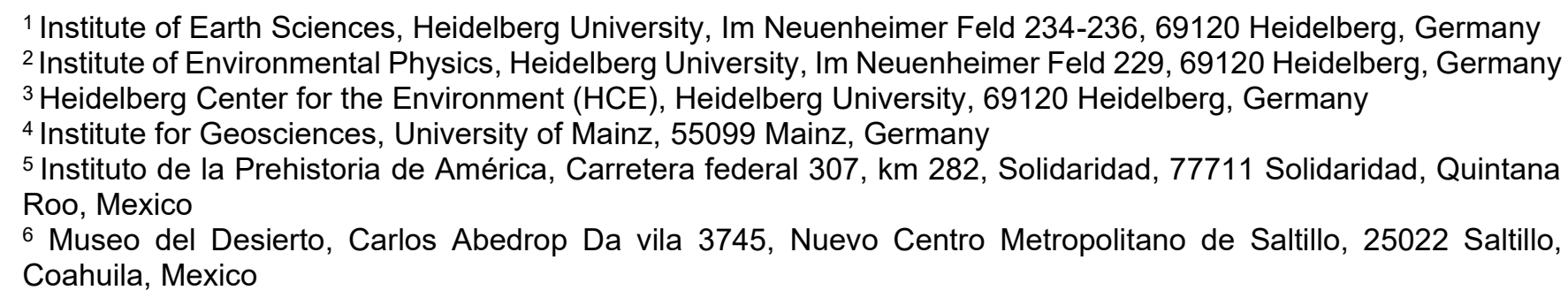

Abstract. Hells Bells are underwater secondary carbonates discovered in sinkholes (cenotes) southeast of Cancun on the north-eastern Yucatán Peninsula, Mexico. These authigenic calcite precipitates, reaching a length of up to $4 \mathrm{~m}$, most likely grow in the pelagic redoxcline. Here, we report on detailed ${ }^{230} \mathrm{Th} / \mathrm{U}$-dating and in-depth geochemical and stable isotope analyses of specimens from cenotes El Zapote, Maravilla and Tortugas. Hells Bells developed during the end of MIS5b/c ( 96-90 thousand years ago) and again since the early Holocene, with active growth until present day. The temporal evolution of the geochemistry and isotope composition of Hells Bells calcites appears closely linked to the mid to late Holocene sea-level rise, which reflects changing hydrological conditions of the aquifer. A stabilization of sea level combined with aquifer occlusion during the past $\sim 8$ thousand years probably led to a reduction in hydraulic conductivity and a desalinization of the freshwater layer as indicated by decreasing $\mathrm{Sr} / \mathrm{Ca}$ values. In addition, initial $\left({ }^{234} \mathrm{U} /{ }^{238} \mathrm{U}\right)$ activity ratios $\left(\delta^{234} \mathrm{U}_{0}\right)$ in the Bells calcite decrease from 55 to $15 \%$ as sea level converges toward its present state. We propose that the Holocene sea-level rise drives 7 desalinization and subsequent deceleration of leaching of excess ${ }^{234} \mathrm{U}$ from the previously unsaturated bedrock. 


\section{Introduction}

29 Impressive bell-shaped speleothems hanging from cavern ceilings and walls were recently discovered in 30-40 m water depth in a small cluster of meromictic sinkholes (e.g., cenote El Zapote) on the north-eastern Yucatán Peninsula (YP) in Mexico (Fig. 1)1. These up to $4 \mathrm{~m}$ long conically downward expanding calcareous structures called Hells Bells were formed underwater ${ }^{1}$. Recently, Hells Bells formation was suggested to initially result from $\mathrm{CO}_{2}$-degassing of ascending gas bubbles that accumulate at cave irregularities and further growth of these structures in the carbonate-saturated freshwater layer of cenote El Zapote ${ }^{2}$. Alternatively, Ritter et al ${ }^{3}$ proposed that the actual growth of Hells Bells is most likely restricted to the pelagic redoxcline, a 1-2 $\mathrm{m}$ thick zone of steep redox-gradients of electron acceptors and reduced chemical species above a sulfidic halocline. The redoxcline overlaps with a distinct milky white horizontal cloud, the turbid layer, into which some Hells Bells partly reach or completely hang inside. Based on hydrogeochemical profiles, a biologically induced authigenic calcite precipitation within the turbid layer was hypothesized ${ }^{1,3}$. In any case, the growth of these speleothems is most likely not continuous. Instead, the corroded lobes of dog-tooth spar crystals and microcrystalline calcite layers of Hells Bells may represent alternating phases of growth and intermittent dissolution, which suggest an episodic elevation of the halocline and, thus, the redoxcline and zone of calcite precipitation ${ }^{1,3}$. So far, the timing of Hells Bells growth remained uncertain since only two small specimens have been ${ }^{230} \mathrm{Th} / \mathrm{U}$-dated yielding ages between 5,200 and 300 years $^{1,2}$. To better constrain the timing and growth rate of Hells Bells, we conducted a systematic study using ${ }^{230} \mathrm{Th} / \mathrm{U}$-dating on several large specimens. In addition, small nodules growing on a drowned tree trunk infer active growth within the redoxcline. Moreover, we have investigated the geochemical composition of these Bells and discovered a small but systematic temporal trend in initial $\left({ }^{234} \mathrm{U} / 238 \mathrm{U}\right)$ activity ratios and the Bells Sr/Ca ratios that seems closely linked to the terminal sea-level rise of the mid to late Holocene. $\left({ }^{234} \mathrm{U} /{ }^{238} \mathrm{U}\right)$ activity ratios are reported here in delta notation $\left(\delta^{234} \mathrm{U}\right.$ values), representing the deviation of $\left.{ }^{234} \mathrm{U} / 238 \mathrm{U}\right)$ from secular equilibrium $\left(\delta^{234} \mathrm{U}=\right.$ $\left.\left({ }^{234} U / 238 U\right)-1\right)$. The initial value of $\delta^{234} U\left(\delta^{234} U_{0}\right)$ can be calculated from the measured $\delta^{234} U_{m}$ by correcting it for the decay of excess ${ }^{234} \mathrm{U}$ since the time of sample formation $(\mathrm{t})$ :

$$
\delta^{234} U_{0}=\delta^{234} U_{m} * e^{\lambda_{234 * t}}
$$

${ }^{234} \mathrm{U}$ and ${ }^{238} \mathrm{U}$ as well as $\mathrm{Sr}$ and $\mathrm{Ca}$ enter freshwater and seawater from host rock dissolution with preferentially leaching of ${ }^{234} \mathrm{U}$ due to the processes of alpha-recoil. In general the $\mathrm{Sr} / \mathrm{Ca}$ ratios and $\delta^{234} \mathrm{U}_{0}$ values are suspected constant for seawater while in cave drip waters and speleothems, Sr/Ca ratios may depend on the amount of precipitation and other processes ${ }^{4-6}$. The $\delta^{234} U_{0}$ value is influenced by several processes, such as the alpha-recoil process, host rock dissolution, and redox-behavior of Uranium ${ }^{7-10}$. In general, the $\delta^{234} \cup_{0}$ value of secondary 
carbonates from the northern YP is close to secular equilibrium ${ }^{11-13}$ and hence lower than the $\delta^{234} U_{0}$ value of seawater $\left(146.8 \pm 0.1 \%{ }^{14}\right)$. In a recent study from southwest Nevada, it was suggested that even under dry conditions (e.g., during periods of a low water table), alpha-recoil causes excess ${ }^{234} \mathrm{U}$ to accumulate in damaged crystal lattice sites and/or on fractured surfaces of the bedrock and sediments, which may then be 'captured' as the water table returns ${ }^{15}$. While ground-waters in general reveal changes of $\delta^{234} U_{0}$ values of several hundred \%o through time, Hells Bells show only very small changes of $<40 \%$ during the last $\sim 8 \mathrm{ky}$. The YP represents an extended limestone platform of horizontally layered carbonate rocks of Cretaceous to Pleistocene ages ${ }^{16,17}$. The Yucatán Karst Aquifer (YKA) hosts the largest known network of underwater caves in the world ${ }^{16,18}$. Climate driven sea-level fall and rise by $>100 \mathrm{~m}^{19}$ caused large parts of the cave system to fall dry and submerge, respectively ${ }^{11,18,20,21}$. Modern water levels were reached around 4.5-3.8 ky ago 20,22,23. The water level of the cenotes in the north-eastern YP is known to be roughly equal to sea level due to connective passages with the Caribbean Ocean and the low hydraulic gradient of about $1-10 \mathrm{~cm} \mathrm{~km}^{-1} 24$. Precipitation rapidly infiltrates through the porous limestone into the underlying coastal aquifer consisting of a meteoric water mass, the freshwater lens, above saline water intruding from the coast ${ }^{25}$. The thickness of the freshwater lens varies between $<10-100$ $\mathrm{m}$ and is generally thinner towards the coast ${ }^{26}$, resulting in a higher salinity of the freshwater lens close to the coast than in inland areas ${ }^{25}$. The halocline separates the meteoric and marine water bodies and is usually characterized by undersaturation with respect to $\mathrm{CaCO}_{3}$, leading to cave formation and conduit enlargement in the coastal carbonate aquifer ${ }^{18,27-29}$.

(a) study area

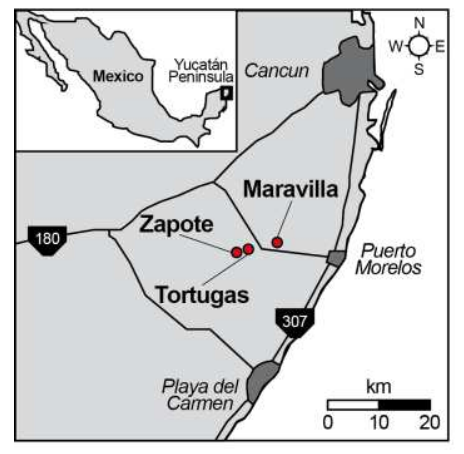

76

77

78

79 (b) Cenote El Zapote

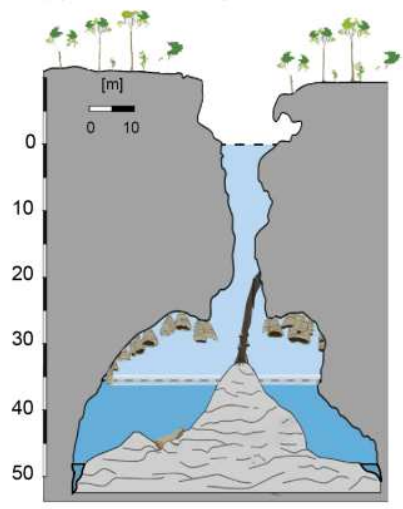

$\square$ freshwater $\square$ halocline

$-\frac{2}{2}$ debris mount (c) Cenote Tortugas

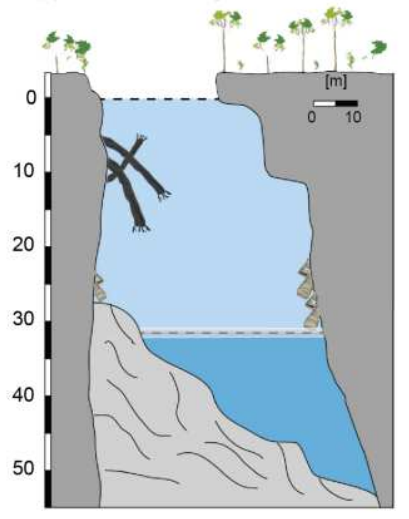

$\square$ saltwater $\square$ redoxcline
Hells Bells $\quad \square$ tree (d) Cenote Maravilla

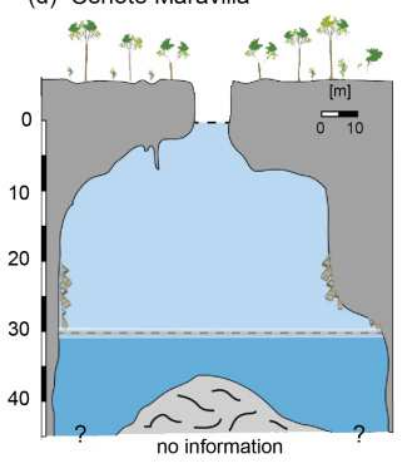

Figure 1: The study area and schematic cross-sections of the investigated cenotes (a) Map of the study area with respect to the Yucatán Peninsula and Mexico. (b-d) Cross-section of the cenotes El Zapote, Tortugas and Maravilla showing the host rock and the sedimentary deposits, such as debris, and Hells Bells speleothems. The grey shaded 


\section{Results}

\section{Hydrogeochemistry of cenote El Zapote}

84 Uranium concentrations are nearly constant at $\sim 12 \mathrm{nmol} \mathrm{L}^{-1}$ in the upper $35 \mathrm{~m}$ of the oxygenated freshwater layer

area at the freshwater-halocline interface refers to the redoxcline, where modern carbonate precipitation is suspected according to Ritter et $\mathrm{al}^{3}$ and Stinnesbeck et $\mathrm{al}^{1}$.
and instantly drop by an order of magnitude as soon as the water becomes anoxic (Supplementary Fig. 1b). $\delta^{234} U$ values are nearly constant throughout the freshwater layer with values of $16 \pm 1 \%$ and increase within the halocline to significantly higher values of $60 \pm 3 \%$ at $45 \mathrm{~m}$ water depth. Uranium concentrations are anticorrelated with $\delta^{234} \mathrm{U}$ values ( $\mathrm{r} \mathrm{U} / \delta 234 \mathrm{U}=-0.68)$.

\section{${ }^{230} \mathrm{Th} / \mathrm{U}$-ages and $\delta^{234} \mathrm{U}_{0}$ values}

${ }^{230} \mathrm{Th} / \mathrm{U}$-dating of Hells Bells samples yielded a large spread of $U$ concentrations ranging by a factor of 15 from $209.893 \pm 0.016$ to $3100 \pm 20 \mathrm{ng} / \mathrm{g}$. ${ }^{232} \mathrm{Th}$ concentrations are variable ranging from $0.16242 \pm 0.00040$ to $5.795 \pm$ $0.015 \mathrm{ng} / \mathrm{g}$ (Supplementary Table 1 ). The measured $\delta^{234} \mathrm{U}$ values vary from $15.1 \pm 1.2$ to $59.9 \pm 4.4 \%$, and the ${ }^{230} \mathrm{Th} / \mathrm{U}$ ages range from recent to as old as $96 \mathrm{ky}$. To estimate the potential influence of initial (either detrital or freshwater derived) excess ${ }^{230} \mathrm{Th}_{\mathrm{xs}}$ on the ${ }^{230} \mathrm{Th} / \mathrm{U}$ age, a first order correction was applied. Here, we assume one single source of contamination with a moderately elevated detrital ( $\left.{ }^{230} \mathrm{Th} /{ }^{232} \mathrm{Th}\right)$ activity ratio of $2 \pm 1$, which is based on previous observations from speleothems of cave sites on the YP and the Caribbean realm ${ }^{11,12,30-34}$. When using this correction model, the corrected ages for the measured Hells Bells samples range from $95.81 \pm 0.52 \mathrm{ky}$ to modern. Initial $\delta^{234} U_{0}$ values vary from $15.1 \pm 1.2$ to $62.6 \pm 4.6 \%$, with the highest values observed in the early Holocene and systematically decreasing values for the mid- to late Holocene (Supplementary Table 1). In fact, $00 \delta^{234} \mathrm{U}_{0}$ values steadily decline in all studied Bells from three different cenotes from $55 \%$ to around $20 \%$ o between $01 \sim 8-4 \mathrm{ky}$, followed by a minor decrease to values of $\sim 15 \%$ o to present (Fig. 2). $\delta^{234} U_{0}$ values from MIS5b/c ( 96-90 $02 \mathrm{ky}$ ago) are intermediate with $30-35 \%$. Overall, $\delta^{234} \cup_{0}$ values from various Bells and cenotes thus reveal an 03 identical temporal variability, which must reflect the isotopic composition of the water in which those carbonates have formed, since there is no fractionation during the incorporation of uranium into carbonates ${ }^{35}$. 


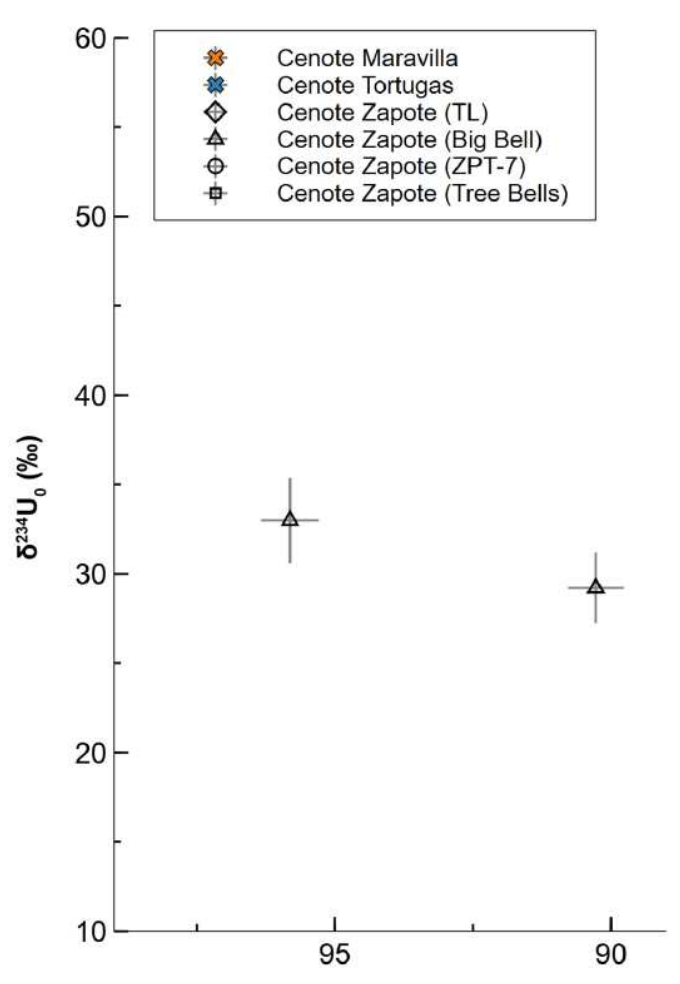

105

106 107 108 109 110 111 $2 \sigma$ margins.

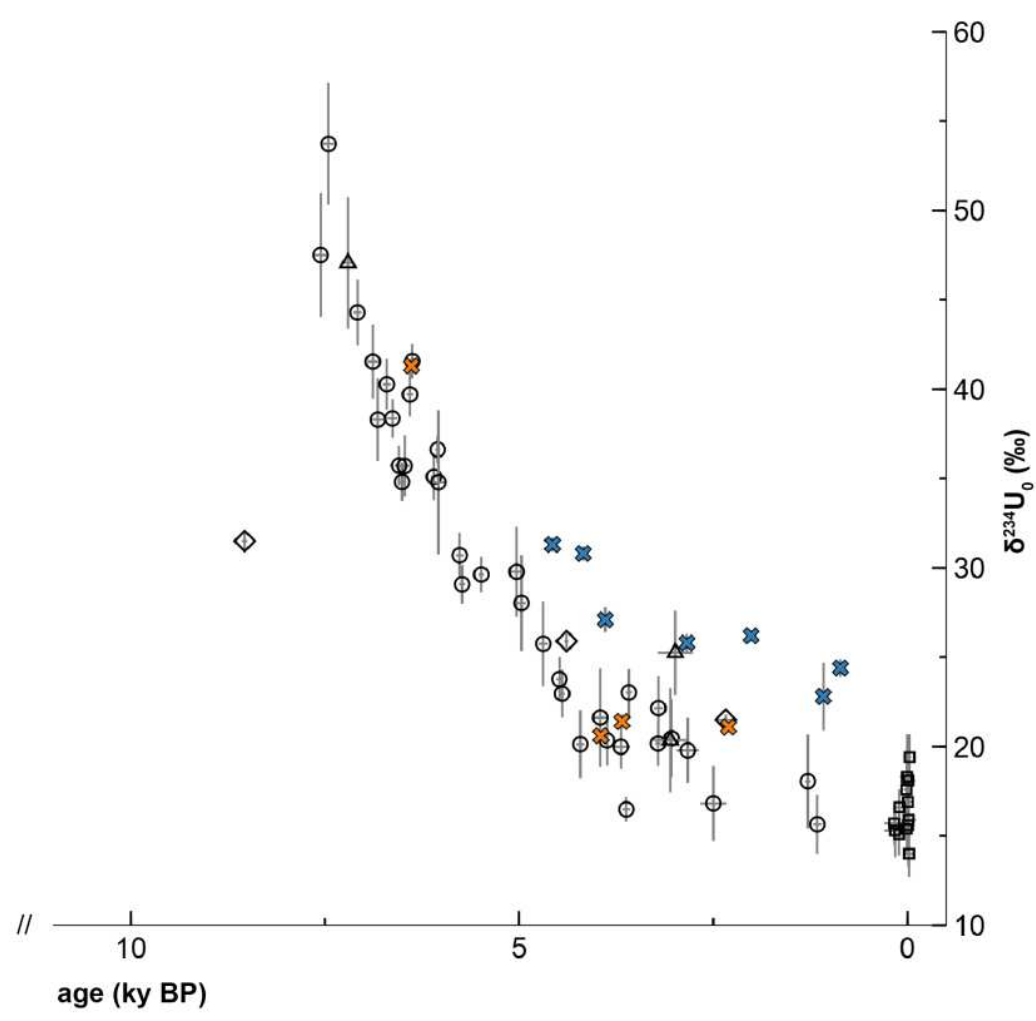

Figure 2: $\delta^{234} U_{0}$ values versus age. Note the broken axis (10-90 ky BP) for absolute ages. Uncertainties are given as

As expected, the root of Big Bell reveals the oldest growth phase dating back to $95.81 \pm 0.52$ ky (Fig. 2 and Supplementary Fig. 2b). Big Bell and ZPT-7 yield ages spanning from the last glacial-interglacial termination to present. The growth of ZPT-7 starts on top of the marine limestone slab (host rock) (Fig. 3; Supplementary Fig. 2c and 3). The determined ages are mostly in stratigraphic order. Layers within $\sim 3.5 \mathrm{~cm}$ distance from the marine limestone slab, yielded ages between 15.5 and 10 ky (Fig. 3, Supplementary Fig. 2c and 3). One of these samples was taken immediately adjacent to a growth interruption, which is macroscopically identified as a black rim conformed by pyrite (Supplementary Fig. 2c). This sample yielded a significantly older age (15.51 $\pm 0.21 \mathrm{ky})$ than the two samples above, thus representing a major stratigraphic inversion. A similar age of $15.02 \pm 0.13 \mathrm{ky}$ was obtained from a sample of the root of Big Bell, which was also sampled near a thin layer of pyrite (Supplementary Fig. 2b). Since we do not know whether the pyrite layer - or the processes that led to its formation - may have had

19 an influence on the geochemistry of the adjacent calcite layers and thus the ${ }^{230} \mathrm{Th} / \mathrm{U}$ ages, or whether this strong 
inversion is the result of a mixture of Hells Bells material of different ages, we exclude these older samples from the following discussion and focus on the mid- to late Holocene samples. From 7.7-2.5 ky, i.e., from $3.7-53.5 \mathrm{~cm}$, the ages of ZPT-7 suggest more regular growth with an average growth rate of about $100 \mu \mathrm{m} \mathrm{yr}^{-1}$ (Fig. 3). At 2.5 ky $(53.5 \mathrm{~cm})$, a growth interruption is evident with a duration of about 1 ky (Fig. 3, Supplementary Fig. 3). The tip of ZPT-7 at $56.7 \mathrm{~cm}$ is dated to an age of $1.284 \pm 0.083 \mathrm{ky}$, which possibly corresponds to the timing of Bell 5 downfall. ${ }^{230} \mathrm{Th} / \mathrm{U}$-dating of the antapical ends of Tree Bells collected from different water depths yielded ages between $0.18 \pm 0.13$ and $0.01 \pm 0.15 \mathrm{ky}$. Moderate uranium concentrations together with high detrital ${ }^{232} \mathrm{Th}$ and a 12 low $\left({ }^{230} \mathrm{Th} /{ }^{232} \mathrm{Th}\right)$ activity ratio result in large age uncertainties of these samples, which, however, are most likely 8 modern.

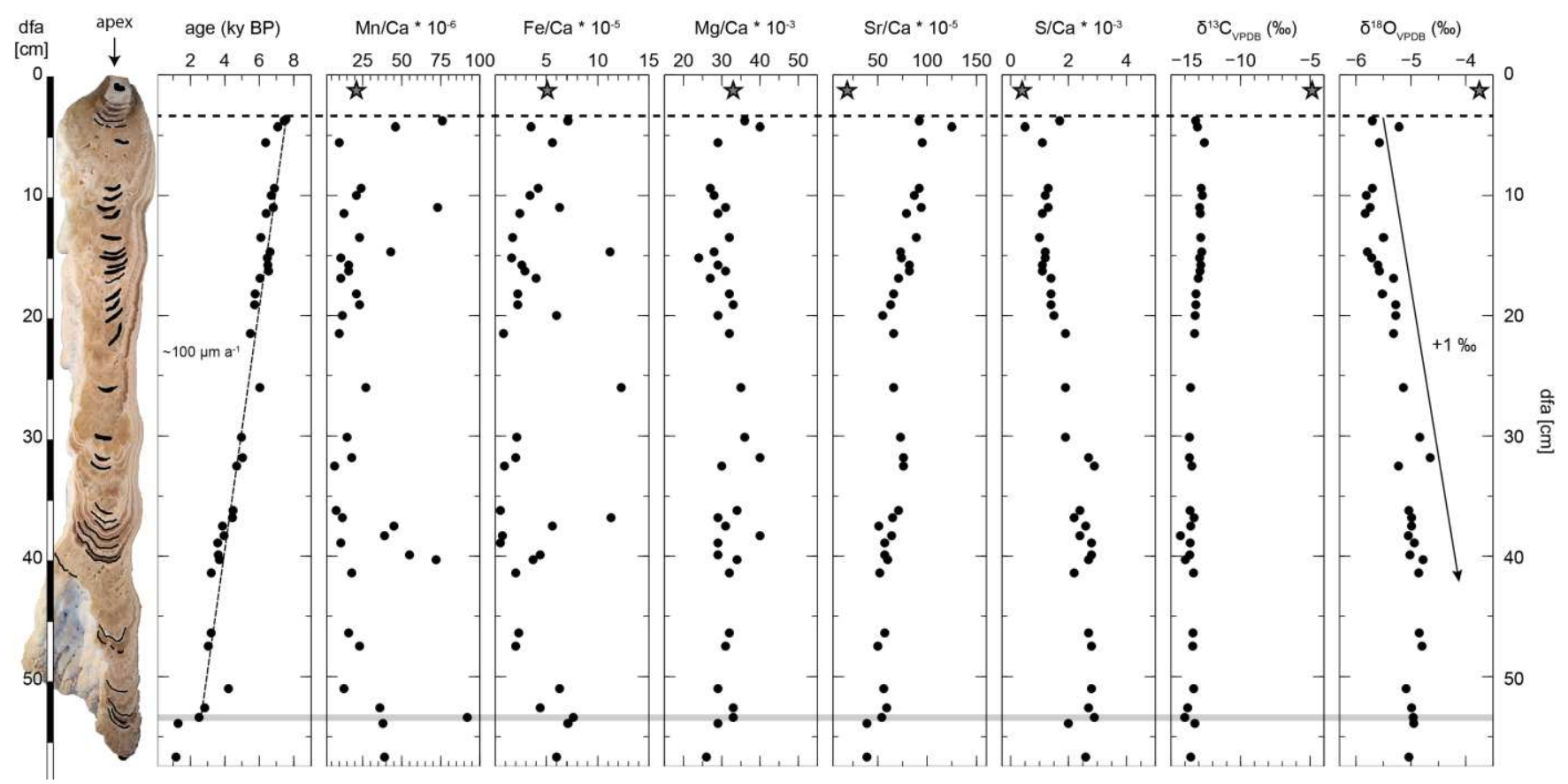

Figure 3: Ages and geochemistry of ZPT-7 along the growth axis. Apical root ends up with carbonate host rock (star symbol). Sample spots are indicated by blackened areas in the image on the left. Major growth discontinuities are highlighted by grey bars. Note the increasing trends of $\delta^{18} \mathrm{O}$ values and molar $\mathrm{S} / \mathrm{Ca}$ ratios as well as the decreasing trends of $\mathrm{Sr} / \mathrm{Ca}$ ratios and $\delta^{13} \mathrm{C}$ values. The ages and geochemical results can be found in Supplementary Table 1 and 2. dfa = distance from the apex. 
136 The host rock carbonate shows stable carbon and oxygen isotope values $\left(\delta^{13} \mathrm{C}\right.$ and $\delta^{18} \mathrm{O}$ values) of $-4.85 \%$ and $137-3.75 \%$, respectively. The $\delta^{13} \mathrm{C}$ and $\delta^{18} \mathrm{O}$ values of the Hells Bells samples are ranging from -11.07 to $-14.32 \%$ 138 and from -6.39 to $-4.34 \%$, respectively. Hence, the $\delta^{13} \mathrm{C}$ and $\delta^{18} \mathrm{O}$ values of Hells Bells are different from those of 139 the host rock. Most samples form a distinct cluster in the stable isotope plot (Fig. 4a), which correspond to the mid140 to late Holocene samples. Here, $\delta^{13} \mathrm{C}$ values correlate inversely with $\delta^{18} \mathrm{O}$ values $\left(r_{\delta 13 /} \delta 180=-0.46\right.$, slope $\left.=-0.85\right)$.

141 There are only a few samples from cenote Tortugas that deviate from this trend, as they exhibit slightly less negative $142 \delta^{13} \mathrm{C}$ values $(-11.36 \%$ on average) than the other samples $(-13.06 \%$ on average). The two oldest samples ( 96 143 and $90 \mathrm{ky}$ ) also plot closely to this cluster and only slightly differ from the rest by showing the most negative $\delta^{18} \mathrm{O}$ 144 values $\left(-6.39 \%\right.$ and $-6.10 \%$ ). The trend in the isotope correlation is also visible through time, with decreasing $\delta^{13} \mathrm{C}$ 145 values and increasing $\delta^{18} \mathrm{O}$ values towards younger ages (Fig. 3 and 4).
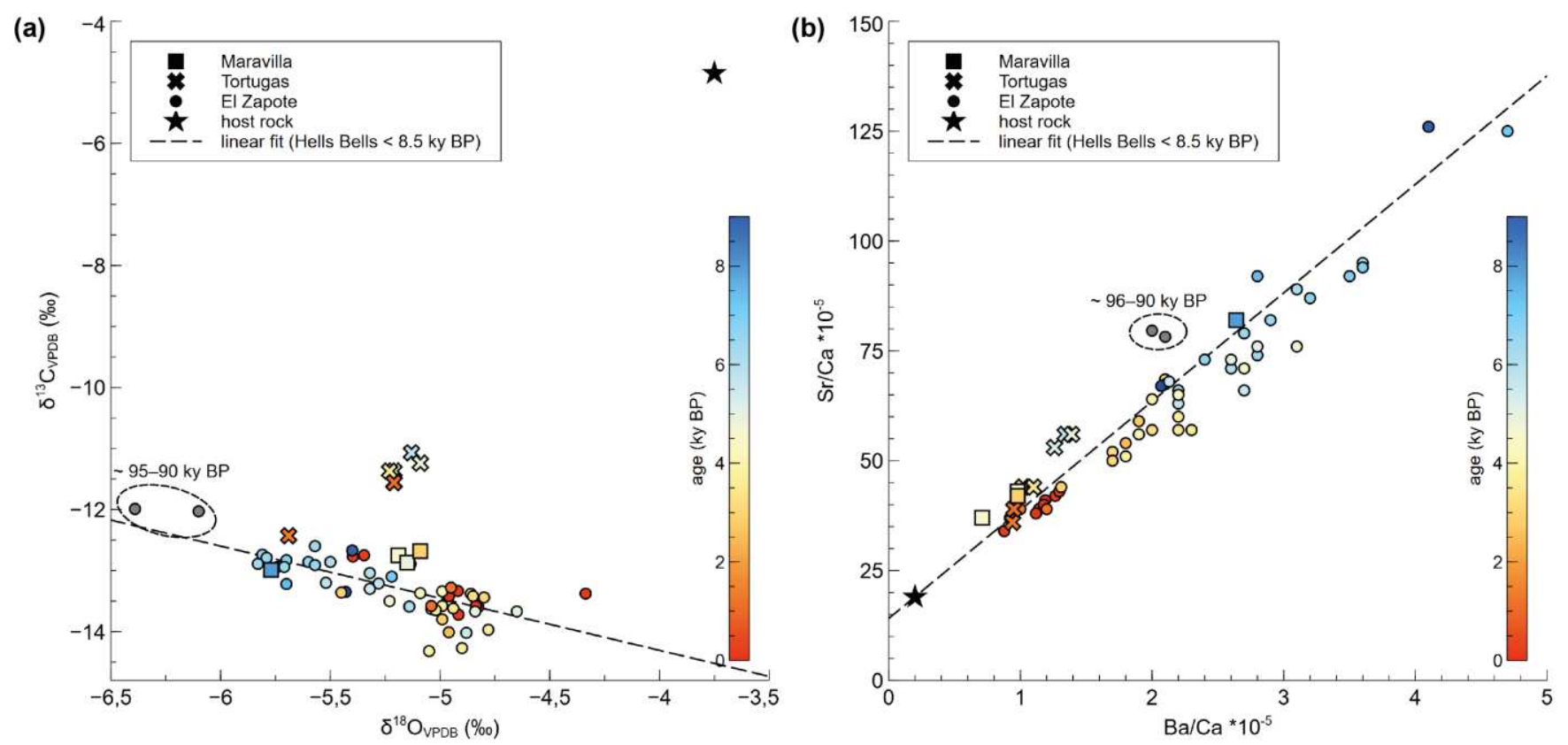

146

Figure 4: Geochemistry of all analyzed Hells Bells samples. The different symbols represent the different cenotes. Samples $<8.5 \mathrm{ky}$ BP are colour-coded depending on their respective age. (a) Stable carbon isotope values $\left(\delta^{13} \mathrm{C}\right)$ plotted against stable oxygen isotope values $\left(\delta^{18} \mathrm{O}\right)$ of all analyzed Hells Bells samples, and the host rock sample from the root of ZPT-7 (EI Zapote cenote). (b) Sr/Ca against Ba/Ca ratios of all analyzed Hells Bells samples and the host rock sample. Sr and $\mathrm{Ba}$ contents of Hells Bells calcite are linearly correlated and indicate that the initial $\mathrm{Sr} / \mathrm{Ba}$ ratio of the host rock is preserved in Hells Bells carbonates. The geochemical results can be found in Supplementary Table 2. 
Hells Bells carbonates show strongly correlated $\mathrm{Sr} / \mathrm{Ca}$ and $\mathrm{Ba} / \mathrm{Ca}$ ratios, and the linear fit intersects with the $\mathrm{Sr} / \mathrm{Ca}$ and $\mathrm{Ba} / \mathrm{Ca}$ ratio of the host rock (Fig. 4b). The ratios of these samples show a decreasing trend with increasing distance from the apex and decreasing age, respectively (Fig. 4b). As for the stable isotopes, the $\mathrm{Sr} / \mathrm{Ca}$ and $\mathrm{Ba} / \mathrm{Ca}$ ratio of the oldest samples (96-90 ky) show slightly different values than the general trend.

Dark, brown-colored layers identified on the polished half of ZPT-7 correspond to elevated $\mathrm{Mn} / \mathrm{Ca}$ and Fe/Ca values (Fig. 3) and show a large scatter. The molar ratio of $\mathrm{Mg} / \mathrm{Ca}\left(24-40 \times 10^{-3}\right)$ appears rather constant through time (Fig. 3). In contrast to the metal/calcium ratios, the multivalent non-metal Sulphur (S) reveals an opposing trend with an increasing S/Ca ratio of ZPT-7 from $\sim 0.1$ to $2.7 \times 10^{-3}$ with decreasing age (Fig. 3). These geochemical trends are thus evident throughout all studied Hells Bells, and even in the nearby cenotes Maravilla and Tortugas (Fig. 4).

\section{Discussion}

\section{${ }^{230} \mathrm{Th} / \mathrm{U}$-chronology and sea level}

Radiometric dating traces the age of carbonate precipitation, and in accordance with relative sea-level elevation during MIS-5b/c and the Holocene, two phases of Hells Bells growth are identified (Fig. 5): (1) From 96-90 ky, i.e., during MIS-5b/c, as indicated by two ages from the root of Big Bell. (2) The Middle to Late Holocene, more specifically most of the last $8.5 \mathrm{ky}$, where the ${ }^{230} \mathrm{Th} / \mathrm{U}$-dating results obtained here provide clear evidence for partly continuous growth of Hells Bells, for example from 7-2.5 ky in ZPT-7, with minor age inversions.

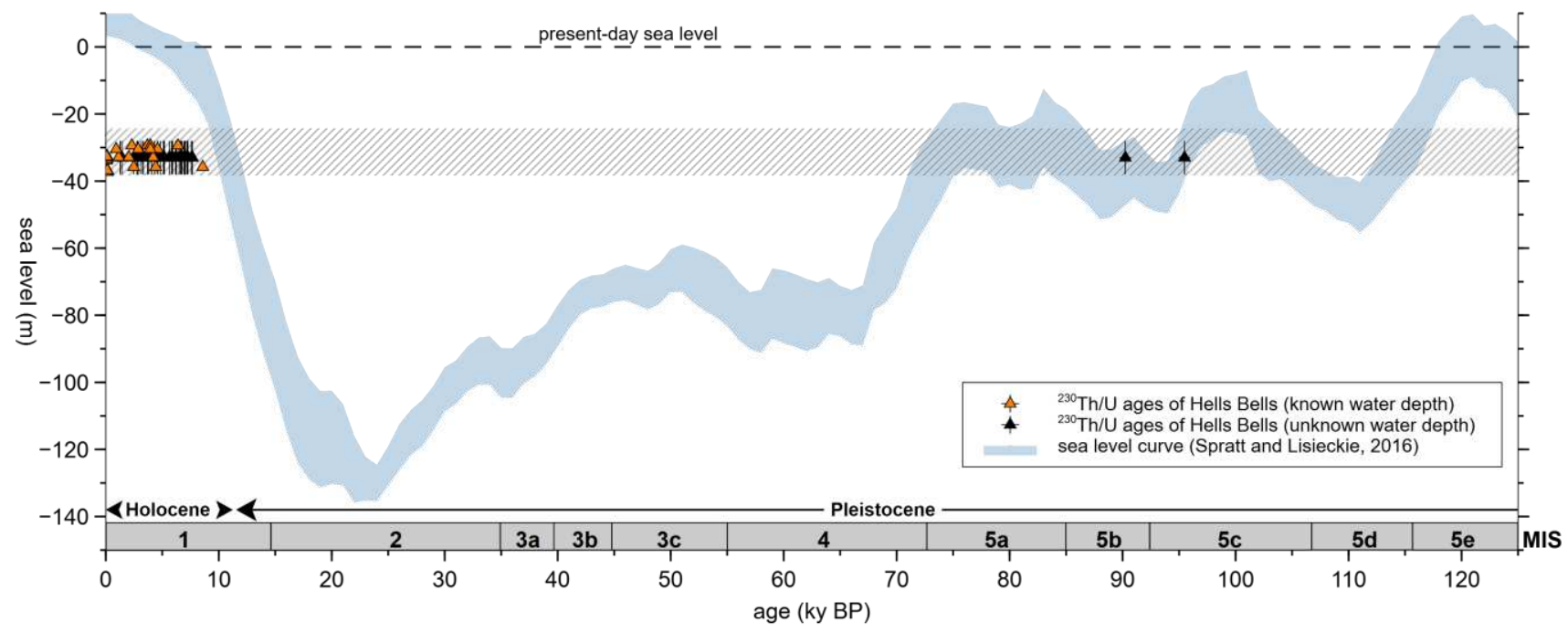


Fig. 5: ${ }^{230} \mathrm{Th} / \mathrm{U}$ ages of Hells Bells samples collected between 29 and $37 \mathrm{~m}$ water depth within the cenotes plotted versus relative sea level from the stack of Spratt and Lisiecki ${ }^{36}$. The original position of Hells Bells samples collected from the floor of cenote El Zapote (black symbols) was estimated to be $33 \pm 5 \mathrm{~m}$ water depth based on the present-day occurrence of Hells Bells in water depths between 28 and $38 \mathrm{~m}$. Due to the subaqueous nature of Hells Bells, the water table and hence sea level, must be at the depth level of the Bells, or above (grey shaded area). Marine isotope substages (MIS) proposed by Railsback et $\mathrm{al}^{37}$ are shown at the bottom.

The two ages of $\sim 96$ and 90 ky obtained from the root of Big Bell reveal that Hells Bells formation is not a phenomenon restricted only to the Holocene, but instead already existed at least since MIS-5b/c (Fig. 5). The extensive hiatus between phase (1) and (2) advocates for a sea-level control on carbonate formation. In times when global sea level was between -38 and -130 m (Fig. 5$)^{36}$, growth of Hells Bells was inhibited, and the exposed carbonate was potentially subject to subaerial weathering, i.e., Bell dissolution or secondary carbonate precipitation from meteoric waters. Thus, pieces of initial Big Bell growth outlasted the aerial exposure during the sea-level lowstand of the last glacial for tens of thousands of years until sea level rose again and growth of Hells Bells reinitiated. The ${ }^{230} \mathrm{Th} / \mathrm{U}$-dating results of ZPT-7 further show that Hells Bells calcite can be dated at century scale resolution. Minor age inversions identified throughout the specimen are likely due to the complex and yet unknown internal structure of Hells Bells and most likely result from deviations from the growth axis during sample collection. The mid- to late Holocene timing of Hells Bells growth confirms previous punctuated observations ${ }^{1,2}$. Between 7.7 and $2.5 \mathrm{ky}(3.7-53.4 \mathrm{~cm}),{ }^{230} \mathrm{Th} / \mathrm{U}$-ages of ZPT-7 show an average growth rate of about $100 \mu \mathrm{m} \mathrm{yr}^{-1}$ (Fig. 3 and Supplementary Fig. 3). These Hells Bells growth rates are in the same order of magnitude as those calculated from ${ }^{230} \mathrm{Th} / \mathrm{U}$-dating by Stinnesbeck et $\mathrm{al}^{1}$ and two orders of magnitude higher than other types of subaqueous speleothems, like mammillary calcite or folia ${ }^{38-40}$. The hand-sized Hells Bells speleothem TL4 from El Zapote and the ones from Maravilla and Tortugas show lower growth rates $\left(\sim 4-18 \mu \mathrm{m} \mathrm{a}^{-1}\right)$ than ZPT-7 $\left(\sim 100 \mu \mathrm{m} \mathrm{a}^{-1}\right)$. One explanation for that might be that those Bells may have experienced continuous changes between growth and dissolution of calcite, resulting in lower net growth since these Bells were hanging in greater depths, i.e., closer to the acidic water below the redoxcline. This assumption is supported by the strong lamination of these samples (Supplementary Fig. 4). The ages of 2.8 and $1.3 \mathrm{ky}$, determined for the lowermost parts of Big Bell and ZPT-7, respectively, may refer to the times when these specimens broke off the cave ceiling and fell on the cave floor, where they stopped growing. Whether these break-offs were gravitationally triggered by the weight of the Bells or even by a devastating event (e.g., earthquake) remains speculative. Interestingly, the age of 1.3 ky coincides with a suspected age of seismic activity on the coast of Quintana Roo and the occurrence of a tsunami deposit ${ }^{41}$. Verification of recent growth of Hells Bells is challenging considering the low growth rates and the partly high concentrations of ${ }^{232} \mathrm{Th}$ (up to $6 \mathrm{ng} / \mathrm{g}$ ) in Tree Bell samples. Nevertheless, the 2-3 mm thick samples collected from 
water depths between 32.7 and 37.3 m yield very young ages of a few decades to centuries (Supplementary Fig. 2a). Thus, we suggest the growth of Hells Bells to be presently active and that the elevation of the halocline, and thus, the zone of Hells Bells growth, varied on the scale of several meters within this period (few decades to centuries).

Overall, the results of the ${ }^{230} \mathrm{Th} / \mathrm{U}$-dating on different Hells Bells specimens from different cenotes on the YP thus reveals two phases of Hells Bells growth. Phase 1 around 96-90 ky and semi-continuous growth of Hells Bells since about 8.5 ky until present (phase 2).

\section{Stable carbon and oxygen isotopes}

The stable carbon isotope record measured in Hells Bells calcite differs distinctively from values determined in the host rock (Fig. 4a). Hells Bells calcite samples of $96-90$ ky show $\delta^{13} \mathrm{C}$-values around $-8 \%$, while Holocene samples reveal values ranging from $-13 \%$ in cenote Zapote to $-11 \%$ in cenote Tortugas. The dissolved $\mathrm{CO}_{2}$ in the redoxcline is fueled by organic matter decomposition in the anoxic saltwater layer and host rock dissolution buffering the acid produced in microbial organic matter decay via sulphate reduction ${ }^{3}$. Consequently, changes in $\delta^{13} \mathrm{C}$ values could reflect a change in vegetation type $\left(\mathrm{C}_{3} / \mathrm{C}_{4}\right.$ plants), a change in vegetation density ( $p \mathrm{CO}_{2}$ of the soil), a change in carbon source (organic matter vs. host rock), or a combination of all of them.

The stable oxygen isotope record measured in Hells Bells calcite mainly depends on the isotopic composition of the freshwater layer, which in turn depends on the isotopic composition of precipitation since groundwater on the YP is a long-term integrator of precipitation and infiltration ${ }^{42}$. There are several studies that have obtained modern $\delta^{18} \mathrm{O}$ values from cenotes with values for groundwater between -2 and $-5 \%{ }^{42-45}$. Long-term monitoring of drip- and groundwater in the Rio Secreto Cave near Playa del Carmen about $30 \mathrm{~km}$ south of our study area (e.g., El Zapote) on the northeast of the YP, showed that the $\delta^{18} \mathrm{O}$ values of groundwater are consistent with the annual amountweighted $\delta^{18} \mathrm{O}$ value of rainfall, while its temporal isotopic stability suggests that it integrates several years of rainfall ${ }^{45}$. In the tropical Atlantic region, $\delta^{18} \mathrm{O}$ values of precipitation are generally linked to summer rainfall amount, a relationship which is based on the type and source of wet season (convective) versus drier season (orographic) rainfall ${ }^{46-48}$. Convective rainfall during the wet summer season associated with frequently occurring tropical storms and hurricanes shows characteristic depleted isotopic values ${ }^{48}$. A study in the northwestern part of the YP showed that the depleted isotopic composition associated with a single hurricane event can disturb the baseline $\delta^{18} \mathrm{O}$ value of groundwater for a few years ${ }^{49}$. Based on these findings, changes in $\delta^{18} \mathrm{O}$ values of Hells Bells calcite may represent long-term changes of local precipitation amount and/or convective activity. The temporal evolution of $\delta^{18} \mathrm{O}$ values in the ZPT-7 speleothem are lowest around $7 \mathrm{ky}$, i.e., the mid-Holocene, and then slightly increase towards modern times. The observation of highest precipitation amounts and/or convective intensity during the 
mid-Holocene and a minor drying trend over the past $\sim 7 \mathrm{ky}$ agrees well with stalagmite records from Guatemala ${ }^{50}$ 237 and Mexico ${ }^{51}$.

\section{Geochemistry and sea level}

239 Due to the low hydraulic gradient (1-10 $\left.\mathrm{cm} \mathrm{km}^{-1}\right)$ of the YKA, the water level within caves and cenotes on the north-

240

242 eastern YP is known to be roughly equal to sea level, especially in areas close (few kilometers distance) to the coast $^{24}$. Hells Bells occur in a narrow depth interval of about $13 \mathrm{~m}$ from -25 to $-38 \mathrm{~m}$ water depth. Ritter et $\mathrm{al}^{3}$ proposed that the actual growth of Hells Bells is most likely restricted to the 1-2 $\mathrm{m}$ thick pelagic redoxcline above a sulfidic halocline. They also suggested an episodic elevation of the halocline and, thus, the redoxcline and zone of calcite precipitation. Hence, the calcite formation reflects the chemical steady state between upward element fluxes, host rock dissolution, and removal of elements from carbonate precipitation and horizontal freshwater flow to the ocean. Under these premises, Hells Bells formation places constrains on the minimum height of the redoxcline and halocline (reflecting the competition of sea level and freshwater layer thickness). This is opposite to the water level constraints obtained from submerged speleothems, which grow in dry caves and therefore provide an upper limit for past water level elevation (sea level) ${ }^{11,52}$.

Geochemical changes of the Bells are well documented in the ratios of $\mathrm{Sr} / \mathrm{Ca}$ and $\mathrm{Ba} / \mathrm{Ca}$, and values of $\delta^{13} \mathrm{C}, \delta^{18} \mathrm{O}$ and $\delta^{234} \mathrm{U}$, which all systematically change throughout the last $\sim 8 \mathrm{ky}$. While the processes driving the geochemical evolution of the Hell Bells calcite are considered highly complex ${ }^{3}$, the continuous change of, for example, $\delta^{234} \mathrm{U}$ values through time is unique. The large spatial scale of systematic geochemical changes of the water interface and calcite chemistry is well attested by Hells Bells samples from the cenotes El Zapote, Maravilla and Tortugas, which show consistently decreasing $\mathrm{Sr} / \mathrm{Ca}$ ratios and thus a decrease in the salinity of the freshwater aquifer during the last $\sim 8 \mathrm{ky}$ (Fig. 6b). Sr/Ca and Cl/Ca ratios of calcite raft deposits in cenotes Ich Balam and Hoyo Negro about $80 \mathrm{~km}$ south of the Hells Bells cenotes show similar changes in the salinity of the freshwater aquifer with a relatively high salinity during the mid-Holocene ( 8.3-7.8 cal ky BP), followed by a continuous decline in salinity over the past $\sim 7 \mathrm{ky}{ }^{25}$. Calcite rafts form at the air-water interface in $\mathrm{CaCO}_{3}$ saturated waters through $\mathrm{CO}_{2}$ degassing and evaporation. They form conically shaped piles as they sink and accumulate on the cave bottom, thereby providing records of the upper part of the freshwater aquifer ${ }^{53}$. On the scale of days to weeks, instrumental monitoring has shown that heavy rainfall events (i.e., hurricanes) can cause turbulent mixing between the marine and the meteoric waters, leading to an increased freshwater salinity ${ }^{54-56}$. Thus, the authors suggest that the decline in aquifer salinity during the last $\sim 7$ ky likely reflects a change in hydrology (drying trend) associated with a decreased freshwater flow in the aquifer ${ }^{25}$. Similarly, benthic microfossils from cenote Aktun $\mathrm{Ha}, 75 \mathrm{~km}$ south of the Hells Bells cenotes, indicate a gradual decrease in freshwater salinity over the past $\sim 4.3 \mathrm{cal} k y \mathrm{BP}^{20}$. They found convincing 
relationships between changing aquifer salinity and late Holocene precipitation patterns. However, the authors also point out that other factors may influence the salinity of the aquifer, such as aquifer occlusion and coastal sedimentation, both long-term processes resulting from sea-level stabilization, which may gradually reduce hydraulic conductivity and turbulent mixing of the aquifer, leading to a desalinization of the freshwater layer ${ }^{20}$. Reconstructions of middle to late Holocene sea-level rise on the YP (Fig. 6a) ${ }^{23}$, represented by a $3^{\text {rd }}$ order polynomial fit of sea-level index points from Mexico and Belize, match extraordinarily well with the pattern of $\mathrm{Sr} / \mathrm{Ca}$ ratios of Hells Bells with an average deviation of $8 \%$ from the sea-level fit (Fig. 6b). These reconstructions are based on archives, such as mangrove peat, corals and microbial mats ${ }^{23}$, and encompass an area from 16.3$20.5^{\circ} \mathrm{N}, 86.5-92.1^{\circ} \mathrm{W}$. Given the clear relationship between a long-term desalinization of the freshwater aquifer and sea-level stabilization, we suggest that on millennial time-scales, sea level acted as the major driver for mid- to late Holocene changes in aquifer hydrogeochemistry on the YP and that drying trends, as suggested by Kovacs et al ${ }^{25}$, rather act on shorter (decadal-centennial) time-scales. This hypothesis gains even more support when looking at temporal changes in $\left({ }^{234} \mathrm{U} / 238 \mathrm{U}\right)$ activity ratios of the aquifer.

The pattern of $\delta^{234} U_{0}$ values matches the progression of middle to late Holocene sea-level rise on the YP even better than that of $\mathrm{Sr} / \mathrm{Ca}$ ratios, presenting an average deviation of only $6 \%$ from the sea-level fit (Fig. 6). Over the past $\sim 8 \mathrm{ky}, \delta^{234} \mathrm{U}_{0}$ values decrease continuously from values around $55-60 \%$ o to values between $15-20 \%$ as sea level converges toward its present state, roughly equivalent to an $8-10 \mathrm{~m}$ sea-level increase (Fig. $6 \mathrm{c})$. $\delta^{234} U_{0}$ values of Hells Bells calcite reflect the $\left({ }^{234} \mathrm{U} /{ }^{238} \mathrm{U}\right)$ activity ratios of the paleo water in which they were formed. There might be several mechanisms involved in controlling $\delta^{234} U$ values of the aquifer. Highly ${ }^{234} U$ enriched $U$ might be delivered from alpha recoil processes and $U$ leaching, or can be supplied by ${ }^{234} U$ deficient $U$ from dissolution of previously leached host rocks ${ }^{57}$. Hence the origin and variability of freshwater $\delta^{234} U$ values and $U$ concentration is complex. Changes in the geochemical environment of the water rock interaction can modify the $\delta^{234} U$ values and $U$ concentrations. Changes in groundwater residence time can lead to uptake of more or less excess ${ }^{234} U$. Accumulation of excess ${ }^{234} \mathrm{U}$ in unsaturated soil or unleached bedrock can cause fluctuations of $\delta^{234} \mathrm{U}$ values related to fluctuations of the water table ${ }^{15}$. Here, isotopic variations are very systematic and occur over large spatial scales. Isotopically enriched $U$ is supplied through diffusion by the underlying saltwater, even if the concentration of uranium in the saltwater body is reduced due to anoxic conditions in which $U$ behaves particle reactive. In contrast, the overlying freshwater seems rather homogeneous and is close to secular equilibrium $(\sim 16 \%$, Supplementary Fig. 1).

In a recent study, Wendt et al ${ }^{15}$ interpreted $\delta^{234} U_{0}$ values of subaqueous calcite from Devils Hole 2 cave as a proxy for water-rock interactions in the regional aquifer. They propose that changes in the elevation of the water table are responsible for changes in the amount of leached excess ${ }^{234} U$ from the bedrock and that variations in $\left({ }^{234} \mathrm{U} /{ }^{238} \mathrm{U}\right)$ 
299 activity ratios therefore coincide with interglacial-glacial cycles. Although the setting of the YKA is distinctly different 300 from that of the Devils Hole in southwest Nevada, they both are subject to recurrent changes in water level elevation 301 on interglacial-glacial timescales. In Nevada, water table fluctuations are driven by variations in recharge amount 302 to the local groundwater flow system ${ }^{58}$, whereas on the YP, they are associated with glacio-eustatic changes in 303 sea level ${ }^{18}$. Similarly to the findings of Wendt et $\mathrm{al}^{15}$, we suggest that the inundation of previously unsaturated 304 bedrock causes a concomitant change in $\delta^{234} U$ values of the groundwater with sea level and hence water table 305 rise as indicated by $\delta^{234} U_{0}$ values of Hells Bells calcite. While we cannot provide unequivocal proof of this 306 hypothesis, the systematic correlation of $\delta^{234} U$ values with sea level is outstanding and suggests that the evolution 307 of $\delta^{234} \mathrm{U}$ values could be used as a regional proxy for the changes in relative sea-level. 


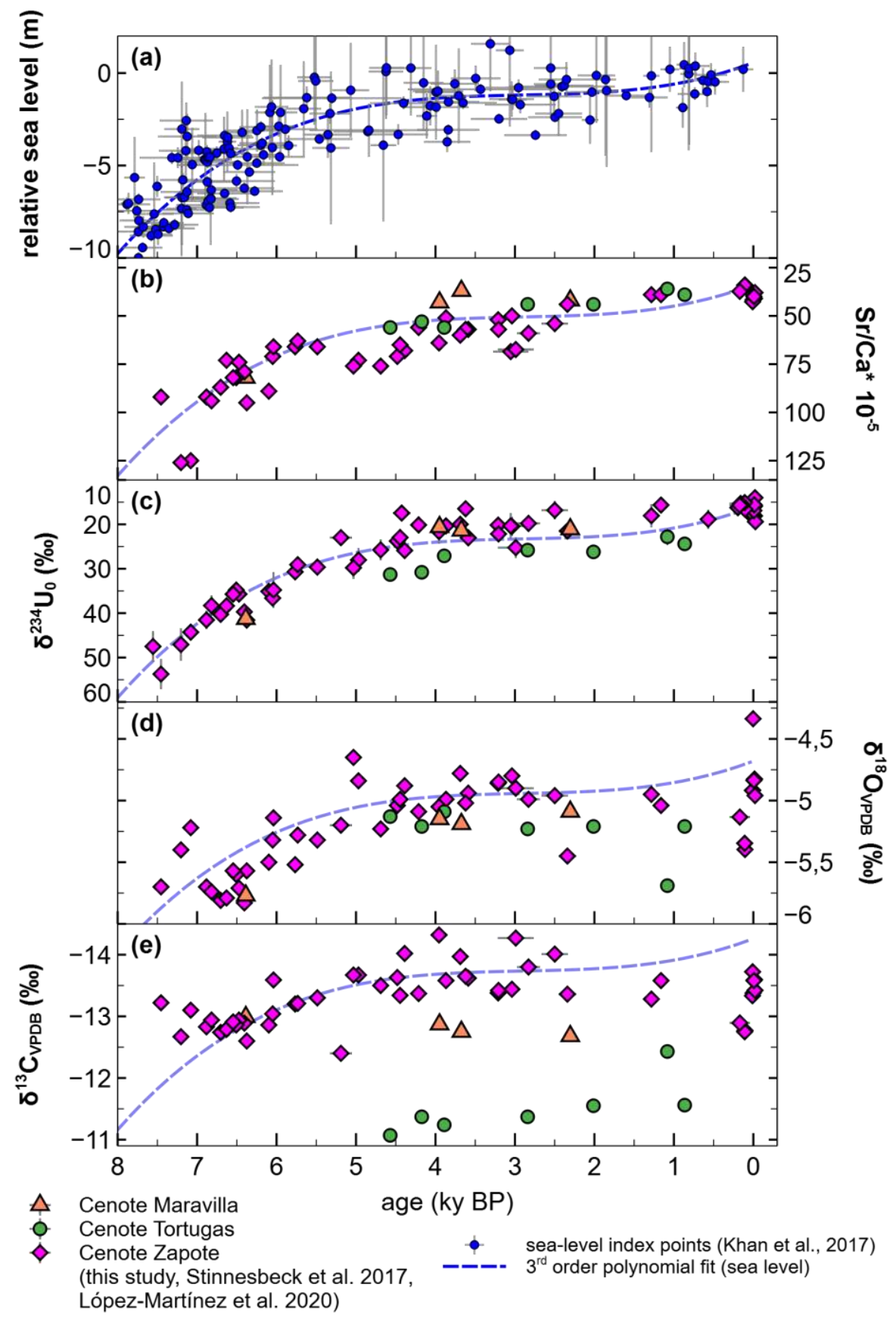

309 Figure 6: Hells Bells geochemistry and sea-level reconstruction during the past 8 ky. (a) Sea level index points from 310 Belize and Mexico ${ }^{23}$. The dashed blue curve is a $3^{\text {rd }}$ order polynomial fit through all data points (b-e) Geochemistry 311 (Sr/Ca ratio, $\delta^{234} U_{0}$, $\delta^{13} \mathrm{C}$-, $\delta^{18} \mathrm{O}$-values) of Hells Bells from cenotes El Zapote, Maravilla and Tortugas during the past 
$\sim 8 \mathrm{ky}$. The very few Hells Bells data available so far from Stinnesbeck et al ${ }^{1}$ and López-Martínez et al ${ }^{2}$ are also shown. The fitted sea-level curve (dashed blue line) is also plotted next to the Hells Bells geochemistry to allow for a more direct comparison to the individual geochemical parameter. Uncertainties are given as $2 \sigma$ margins.

\section{Conclusions}

Data obtained from ${ }^{230} \mathrm{Th} / \mathrm{U}$-dating, geochemical and stable isotope analyses of several Hells Bells specimens from the cenotes El Zapote, Maravilla and Tortugas on the north-eastern Yucatán Peninsula show that geochemical records of subaqueous grown Hells Bells speleothems can be used as a proxy for paleo-hydrological conditions of the local aquifer. The oldest ages (96-90 ky BP) even reach back to MIS5b/c and thus indicate that Hells Bells outlasted aerial exposure during sea-level low-stands of the last glacial period and future the potential to identify earlier phases of growth. ${ }^{230} \mathrm{Th} / \mathrm{U}$-dating of the lowermost parts of Hells Bells and thus their youngest endings suggest that growth reaches to modern times and is an ongoing process. Geochemical ( $\mathrm{Sr} / \mathrm{Ca}$ ratios) and isotopic trends of $\delta^{234} U_{0}$ values of Hells Bells calcites over the past $\sim 8$ ky follow the gradual increase and stabilization of sea level well. We suggest that a stabilization of sea level towards the late Holocene probably led to a desalinization of the freshwater layer as indicated by decreasing $\mathrm{Sr} / \mathrm{Ca}$ ratios. This is the first study to show that decreasing $\delta^{234} \mathrm{U}_{0}$ values of Hells Bells coincide with the final Holocene sea-level rise in the Caribbean. We propose that with the deceleration of Holocene sea-level rise towards its present state, the contribution of accumulated excess ${ }^{234} \mathrm{U}$ to the aquifer decreased equally, and thus causes this unique empirical relationship. If future studies confirm this observation, the $\delta^{234} \mathrm{U}$ values of Hells Bells calcites could be used as a regional proxy for sea-level reconstruction in that region.

\section{Methods}

\section{Hells Bells samples}

The three studied cenotes (El Zapote, Tortugas and Maravilla) are located southwest of Cancún, in the Mexican federal state of Quintana Roo (Fig. 1). Cenote El Zapote $\left(20^{\circ} 51^{\prime} 27.78^{\prime \prime} \mathrm{N} 87^{\circ} 07^{\prime} 35.93^{\prime \prime} \mathrm{W}\right.$ ) is water-filled and connected to the surface by a $28 \mathrm{~m}$ deep vertical shaft (Fig. 1a). The freshwater lens and the saline water mass are separated by a thick halocline reaching from 36.7-51.7 $\mathrm{m}$ water depth (Fig. 1a) ${ }^{59}$. At $28 \mathrm{~m}$ depth below the water level, the cave walls diverge almost horizontally and form a 60 to $>100 \mathrm{~m}$ wide cavern, reaching to a depth of $54 \mathrm{~m}^{1}$. A $20 \mathrm{~m}$ high debris mound in the center of the cave is built up by limestone blocks and smaller debris, large stems of jungle trees and other vegetation falling in from the surface as well as abundant organic matter ${ }^{1}$. Hells Bells hanging from the cavern ceiling and walls and reaching lengths of up to $>4 \mathrm{~m}$ appear in water depths of 
28-38 m (Fig. 1a) $)^{1}$. Cenote Tortugas $\left(20^{\circ} 51^{\prime} 11.7^{\prime \prime} \mathrm{N} 87^{\circ} 06^{\prime} 30.1^{\prime \prime} \mathrm{W}\right)$ is located $24 \mathrm{~km}$ west of Puerto Morelos coast and about $2 \mathrm{~km}$ east of cenote El Zapote. The cenote shows a large circular opening of about $25 \mathrm{~m}$ diameter and is slightly asymmetric in cross-section (Fig. 1b). A debris mound lies against the wall of one side of the cenote and dips towards the opposite side from 25 to around $60 \mathrm{~m}$ water depth. Here, Hells Bells appear in water depths from 25-35 $\mathrm{m}^{1}$. Cenote Maravilla is located about $16 \mathrm{~km}$ west of the coast of Puerto Morelos $\left(20^{\circ} 52^{\prime} 18.9^{\prime \prime} \mathrm{N}\right.$ $87^{\circ} 01^{\prime 2} 24.5^{\prime \prime} \mathrm{W}$ ). The cenote is bottle-shaped in cross section with a central debris mound (Fig. 1c). Hells Bells appear in water depths from $\sim 19$ to at least $32 \mathrm{~m}$. The selected Hells Bells are composed of horizontally laminated calcite layers, with the lowermost (youngest) parts of the Bells frequently ending into $\mathrm{mm}$ to $\mathrm{cm}$ sized, elongated dog-tooth calcite crystals ${ }^{1,3}$.

Here we study three different types of Hells Bells samples from cenote El Zapote. (1) The root and bottom of a 1.8 $\mathrm{m}$ long Hells Bells specimen termed Big Bell. This specimen was recovered from the cenote floor in 2017 and is presently displayed at the visitor center of El Zapote Eco Park. A slice of the uppermost root was cut with a diamond saw and was polished subsequently. Samples were drilled perpendicularly to the presumed growth axis with a Dremel tool using a diamond coated stainless-steel drill. Samples from the bottom of Big Bell were manually removed and homogenized by grinding in an agate mortar. (2) An elongated $\sim 60 \mathrm{~cm}$ long Hells Bells specimen called ZPT- $7^{1}$ was - as the Big Bell - collected from the floor of cenote El Zapote. It was vertically cut in half, thin sections were prepared from one half, and the other half was polished. ZPT-7 samples were drilled along the presumed growth axes and along visual growth layers of about 0.5-1 mm thickness. (3) Some smaller Hells Bells of 5-8 cm size (Tree Bells) growing over a range of $\sim 5 \mathrm{~m}$ water depth on a tree trunk that has fallen into the cenote. These carbonates were collected in June 2017 from seven water depth levels between 31.3 and $37.3 \mathrm{~m}$. Their geochemical composition (trace elements and stable isotopes) was previously published by Ritter et al. ${ }^{3}$. To obtain the youngest parts of individual Hells Bells, the samples were microscopically studied, and only samples with apparently fresh, well-accentuated crystal tips were chosen for further analyses. The sampling of the small Tree Bell fragments differs from the others since the sample material for ${ }^{230} \mathrm{Th} / \mathrm{U}$-dating was not taken as aliquots from a homogeneous powder used for geochemical analysis. Here, sample material for dating was taken close to the areas where sample material for geochemical analysis was collected. In 2018, additional small Hells Bells were collected in cenote El Zapote (TL4), but also from the nearby cenotes Maravilla (MIII) and Tortugas (T7 and T12). They were vertically cut, samples for geochemical analyses were drilled, and thin sections prepared. In the following, all depth information on Hells Bells samples refers to the distance from the apex. Aliquots of all samples were taken for the subsequent geochemical analyses. In addition to carbonate samples, water at cenote El Zapote was sampled in 2018. Water samples between 0-36 m were retrieved using a $0.5 \mathrm{~m}$ high Polyethylene FreeFlow bottle (HYDRO-BIOS, Kiel, Germany), and samples between 36-52 m were collected by technical divers by 
drawing up the water of the desired sampling depth into $140 \mathrm{ml}$ sterile PE-luer-lock syringes with an attached threeway valve.

\section{${ }^{230} \mathrm{Th} / \mathrm{U}$-dating}

In total, $73^{230} \mathrm{Th} / \mathrm{U}$ ages of Hells Bells samples were analyzed by MC-ICP-MS (Thermo Fisher Neptune ${ }^{\text {plus}}$ ) at the Universities of Heidelberg and Mainz. The applied sample treatment, mass spectrometry and data treatment are detailed in previously published work ${ }^{60-63}$. Solid Tree Bell samples were pre-cleaned through a weak acid leach and dried prior to dissolution in $7 \mathrm{~N} \mathrm{HNO}_{3}$. The chemical preparation consisted of a $\mathrm{U}$ and Th purification using UTEVA (HD) or AG1-X8 (Mainz) resin through manual chemistry60,63. U-series isotope measurements were conducted with a semi-static multi-cup setting according to $\operatorname{Arps}^{64}$ (HD) or Obert et al ${ }^{61}$ (Mainz). Ages were calculated using the half-lives of Cheng et $\mathrm{al}^{65}$. All ${ }^{230} \mathrm{Th} / \mathrm{U}$-ages are reported relative to the year 1950 (BP). Uncertainties are reported at the $2 \sigma$-level, and do not include half-life errors.

\section{Major and trace element analysis}

About $3 \mathrm{mg}$ of each powdered carbonate were digested in $2 \mathrm{~mL}$ of $10 \% \mathrm{HNO}_{3}$ for major and trace element analyses. Subsequently, concentrations of $\mathrm{Ca}, \mathrm{Mg}, \mathrm{Sr}, \mathrm{Ba}, \mathrm{S}, \mathrm{Fe}$ and $\mathrm{Mn}$ of diluted aliquots were determined by ICP-OES at Heidelberg University. Quality control of the measurement was performed using reference materials SPS-SW1 and SPS-SW2 with recovery rates of $\sim 100 \%$ for the analyzed elements. Quality control of the digestion of the carbonate material was performed with analyses of parallel aliquots of the limestone reference material ECRM 752-1. The recovery rate of the certified values was $\sim 100 \%$ for the elements $\mathrm{Ca}, \mathrm{Mg}, \mathrm{Sr}$, Fe and $\mathrm{Mn}$, while a yield of $\sim 90 \%$ was achieved for the element $\mathrm{Ba}$ and $\sim 80 \%$ for the element Fe. The resulting element to Ca ratios are presented as molar ratios.

\section{Stable carbon and oxygen isotope measurements}

For stable carbon and oxygen isotope analyses of carbonates, approximately 50-90 $\mu \mathrm{g}$ of powdered speleothem subsamples were analyzed using a ThermoFinnigan MAT253Plus gas source mass spectrometer equipped with a Thermo Fisher Scientific Kiel IV carbonate device at Heidelberg University (Institute of Earth Sciences). The $\delta^{13} \mathrm{C}$ and $\delta^{18} \mathrm{O}$ values are reported relative to VPDB through the analysis of an in-house standard (Solnhofen limestone, $\delta^{13} \mathrm{C}_{\mathrm{VPDB}}=+1.38 \pm 0.03 \%$ and $\delta^{18} \mathrm{OVPDB}=-4.59 \pm 0.06 \%$ ) calibrated to the reference material IAEA-603 (calcite; $\delta^{13} \mathrm{C}_{\mathrm{VPDB}}=+2.46 \pm 0.01 \%$ and $\delta^{18} \mathrm{OVPDB}_{\mathrm{VP}}=-2.37 \pm 0.04 \%$ ). External precisions (repeatable measurements of inhouse standard) for $\delta^{13} \mathrm{C}$ and $\delta^{18} \mathrm{O}$ values were better than 0.03 and $0.06 \%$ (at $1 \sigma$ level, $n>12$ ), respectively. 


\section{Data availability}

The raw data of the figures and tables presented in this paper are found in the Supplement.

\section{Author contributions}

NF, SR, WS, and NS conceptualized this study. NS conducted all analysis of carbonate and water samples and performed the data quality control. SR, NS, and CS performed geochemical analysis of water samples and contributed to the discussion of the geochemical data in relation to Hells Bells growth. NF, SW, DS, MW and NS participated in the ${ }^{230} \mathrm{Th} / \mathrm{U}$ dating and quality control of $\mathrm{U}$-series data and interpretation. WS and JOA provided the samples and information on the Hells Bells environment. FK contributed stable carbon and oxygen isotope analyses. NS and SR collected the data and NF, CS, FK validated it. All authors participated in the writing of the manuscript.

\section{Competing interests}

The authors declare that they have no conflict of interest.

\section{Acknowledgements}

This research was funded by the Deutsche Forschungsgemeinschaft (grants STI128/28, STI128/36, KE 884/8-2, SCHO 1274 11-1 and INST 247/889-1 FUGG), and the CONACYT-FONCICYT-DADC (grant no. 000000000278227). We gratefully acknowledge the owners of Cenote Zapote Ecopark: Rosario Fátima González Alcocer and Santos Zuñiga Roque, and their team members, Daniel de Jesus Tum Canul, Israel Mendez Castro and Eunice Mendez Castro de la Cruz, for granting us access to the cenote and their great support during field work. We would like to thank the technical cave divers Luz Maria Guzman, Vicente Fito, Eugenio Aceves, Valentina Cucchiara, Andrea Anton, Tamara Adame, Christine Lowe and Dirk Penzel, Red de Planetarios de Quintana Roo Directors; Karla Peregrina, Milagros Vazquez, Roberto Rojo and Vicente Hernandez. We thank René Eichstädter, S. Rheinberger, B. Knape, M. Greule and Jennifer Klose for analytical support.

\section{References}

Stinnesbeck, W. et al. Hells Bells - unique speleothems from the Yucatan Peninsula, Mexico, generated under highly specific subaquatic conditions. Paleogeogr. Paleoclimatol. Paleoecol. 489, 209-229, doi:https://doi.org/10.1016/j.palaeo.2017.10.012 (2017). 
López-Martínez, R. et al. Bubble trail and folia in cenote Zapote, México: petrographic evidence for abiotic precipitation driven by $\mathrm{CO} 2$ degassing below the water table. International Journal of Speleology (Edizione Italiana), doi:10.5038/1827-806X.49.3.2344 (2020).

Ritter, S. M. et al. Subaqueous speleothems (Hells Bells) formed by the interplay of pelagic redoxcline biogeochemistry and specific hydraulic conditions in the El Zapote sinkhole, Yucatan Peninsula, Mexico. BIOGEOSCIENCES 16, 2285-2305, doi:https://doi.org/10.5194/bg-16-2285-2019 (2019). in a Chinese speleothem: The potential for high-resolution paleomonsoon reconstruction. EARTH PLANET SC LETT 244, 394-407, doi:10.1016/j.eps1.2006.01.064 (2006).

Cruz, F. W. et al. Evidence of rainfall variations in Southern Brazil from trace element ratios $(\mathrm{Mg} / \mathrm{Ca}$ and $\mathrm{Sr} / \mathrm{Ca})$ in a Late Pleistocene stalagmite. GEOCHIM COSMOCHIM AC 71, 2250-2263, doi:10.1016/j.gca.2007.02.005 (2007). GEOL 294-295, 1-17, doi:https://doi.org/10.1016/j.chemgeo.2011.10.008 (2012).

Bonotto, D. M. \& Andrews, J. The mechanism of $234 \mathrm{U} 238 \mathrm{U}$ activity ratio enhancement in karstic limestone groundwater. CHEM GEOL 103, 193-206 (1993).

Paces, J. B., Ludwig, K. R., Peterman, Z. E. \& Neymark, L. A. 234U/238U evidence for local recharge and patterns doi:10.1016/s0883-2927(02)00037-9 (2002).

Maher, K. et al. Uranium isotopes in soils as a proxy for past infiltration and precipitation across the western United States. Am. J. Sci. 314, 821-857, doi:10.2475/04.2014.01 (2014). doi:10.1016/j.apgeochem.2018.10.002 (2018). doi:10.1038/s41598-021-93417-z (2021). Holocene. Earth and Space Science Open Archive, doi:10.1002/essoar.10502455.1 (2020). 

composition. Geochemistry, Geophysics, Geosystems 11, 8, doi:https://doi.org/10.1029/2010GC003318 (2010).

Wendt, K. et al. Paleohydrology of southwest Nevada (USA) based on groundwater 234U/238U over the past 475 k.y. GSA Bulletin, doi:10.1130/B35168.1 (2019). 7613(1995)023 $<0873:$ Ynssia $>2.3 . C o ; 2$ (1995).

Smart, P. L. et al. in Perspectives on Karst Geomorphology, Hydrology, and Geochemistry - A Tribute Volume to of America, 2006). (1995).

van Hengstum, P. J., Reinhardt, E. G., Beddows, P. A. \& Gabriel, J. J. Linkages between Holocene paleoclimate and paleohydrogeology preserved in a Yucatan underwater cave. QUATERNARY SCI REV 29, 2788-2798, doi:https://doi.org/10.1016/j.quascirev.2010.06.034 (2010).

21 Collins, S. V. et al. Reconstructing water level in Hoyo Negro, Quintana Roo, Mexico, implications for early Paleoamerican and faunal access. QUATERNARY SCI REV 124, 68-83, doi:https://doi.org/10.1016/j.quascirev.2015.06.024 (2015).

22 Torrescano, N. \& Islebe, G. A. Tropical forest and mangrove history from southeastern Mexico: a $5000 \mathrm{yr}$ pollen record and implications for sea level rise. VEG HIST ARCHAEOBOT 15, 191-195, doi:http://dx.doi.org/10.1007/s00334-005-0007-9 (2006). doi:https://doi.org/10.1007/s10040-010-0699-5 (2011). 
25 Kovacs, S. E. et al. Calcite raft geochemistry as a hydrological proxy for Holocene aquifer conditions in Hoyo Negro and Ich Balam (Sac Actun Cave System), Quintana Roo, Mexico. QUATERNARY SCI REV 175, 97-111, doi:https://doi.org/10.1016/j.quascirev.2017.09.006 (2017).

Beddows, P. A., Smart, P., Whitaker, F. \& Smith, S. in Karst Waters Institute Special Publication 7: Hydrogeology and Biology of Post-Paleozoic Carbonate Aquifers (eds J. B. Martin, C.M. Wicks, \& I.D. Sasowsky) 129-134 (2002).

27 Back, W., Hanshaw, B. B., Herman, J. S. \& Van Driel, J. N. Differential dissolution of a Pleistocene reef in the ground-water mixing zone of coastal Yucatan, Mexico. GEOLOGY 14, 137-140, doi:https://doi.org/10.1130/00917613(1986)14<137:DDOAPR >2.0.CO;2 (1986).

Gulley, J. D., Martin, J. B. \& Brown, A. Organic carbon inputs, common ions and degassing: rethinking mixing dissolution in coastal eogenetic carbonate aquifers. EARTH SURF PROC LAND 41, 2098-2110, doi:https://doi.org/10.1002/esp.3975 (2016).

30 Warken, S. et al. Persistent link between Caribbean precipitation and Atlantic Ocean circulation during the Last Glacial revealed by a speleothem record from Puerto Rico. (2020).

31 Moseley, G. E. et al. Early-middle Holocene relative sea-level oscillation events recorded in a submerged speleothem from the Yucatán Peninsula, Mexico. The Holocene 25, 1511-1521, doi:https://doi.org/10.1177\%2F0959683615585832 (2015).

Stinnesbeck, W. et al. New evidence for an early settlement of the Yucatán Peninsula, Mexico: The Chan Hol 3 woman and her meaning for the Peopling of the Americas. PLOS ONE 15, e0227984, doi:10.1371/journal.pone.0227984 (2020).

Beck, J. W. et al. Extremely large variations of atmospheric 14C concentration during the last glacial period. Science 292, 2453-2458 (2001).

34 Hoffmann, D. L. et al. Towards radiocarbon calibration beyond 28ka using speleothems from the Bahamas. EARTH PLANET SC LETT 289, 1-10, doi:https://doi.org/10.1016/j.epsl.2009.10.004 (2010).

Chen, J. H., Lawrence Edwards, R. \& Wasserburg, G. J. 238U,234U and232Th in seawater. EARTH PLANET SC LETT 80, 241-251, doi:10.1016/0012-821x(86)90108-1 (1986).

Spratt, R. M. \& Lisiecki, L. E. A Late Pleistocene sea level stack. CLIM PAST 12, 1079-1092, doi:https://doi.org/10.5194/cp-12-1079-2016 (2016). 
37 Railsback, L. B., Gibbard, P. L., Head, M. J., Voarintsoa, N. R. G. \& Toucanne, S. An optimized scheme of lettered marine isotope substages for the last 1.0 million years, and the climatostratigraphic nature of isotope stages and substages. QUATERNARY SCI REV 111, 94-106, doi:https://doi.org/10.1016/j.quascirev.2015.01.012 (2015).

Drysdale, R. N. et al. Precise microsampling of poorly laminated speleothems for U-series dating. Quaternary Geochronology 14, 38-47, doi:https://doi.org/10.1016/j.quageo.2012.06.009 (2012).

39 Plummer, L. N., Busenberg, E. \& Riggs, A. C. In-situ Growth of Calcite at Devils Hole, Nevada: Comparison of Field and Laboratory Rates to a 500,000 Year Record of Near-Equilibrium Calcite growth. Aquatic Geochemistry 6, 257274, doi:10.1023/a:1009627710476 (2000).

40 De Waele, J. et al. Speleothems in a north Cuban cave register sea-level changes and Pleistocene uplift rates. EARTH SURF PROC LAND 43, 2313-2326, doi:10.1002/esp.4393 (2018).

41 Lario, J. et al. An extreme wave event in eastern Yucatán, Mexico: Evidence of a palaeotsunami event during the Mayan times. Sedimentology 67, 1481-1504, doi:10.1111/sed.12662 (2020). in the Peninsula of Yucatan, Mexico. HYDROL EARTH SYST SC 2020, 1-20, doi:https://doi.org/10.5194/hess-2020$\underline{16}(2020)$.

43 Socki, R. A., Perry, E. J. C. \& Romanek, C. S. Stable isotope systematics of two cenotes from the northern Yucatan Peninsula, Mexico. LIMNOL OCEANOGR 47, 1808-1818, doi:https://doi.org/10.4319/lo.2002.47.6.1808 (2002).

44 Wassenaar, L. I., Van Wilgenburg, S. L., Larson, K. \& Hobson, K. A. A groundwater isoscape ( $\delta \mathrm{D}, \delta 18 \mathrm{O})$ for Mexico. J GEOCHEM EXPLOR 102, 123-136, doi:https://doi.org/10.1016/j.gexplo.2009.01.001 (2009).

45 Lases-Hernandez, F., Medina-Elizalde, M., Burns, S. \& DeCesare, M. Long-term monitoring of drip water and groundwater stable isotopic variability in the Yucatán Peninsula: Implications for recharge and speleothem rainfall reconstruction. GEOCHIM COSMOCHIM AC 246, 41-59, doi:https://doi.org/10.1016/j.gca.2018.11.028 (2019).

46 Govender, Y., Cuevas, E., Sternberg, L. D. S. \& Jury, M. R. Temporal Variation in Stable Isotopic Composition of Rainfall and Groundwater in a Tropical Dry Forest in the Northeastern Caribbean. Earth Interactions 17, 1-20, doi:https://doi.org/10.1175/2013ei000534.1 (2013).

47 Lases-Hernandez, F., Medina-Elizalde, M. \& Benoit Frappier, A. Drip water $\delta 180$ variability in the northeastern Yucatán Peninsula, Mexico: Implications for tropical cyclone detection and rainfall reconstruction from speleothems. GEOCHIM COSMOCHIM AC, doi:https://doi.org/10.1016/j.gca.2020.07.008 (2020). 

NEXRAD echo tops, Luquillo Mountains, Puerto Rico. Water Resources Research 45, doi:https://doi.org/10.1029/2008WR007515 (2009).

Perry, E. C., Velasquez-Oliman, G. \& Socki, R. A. in The Lowland Maya Area: Three Millennia at the HumanWildland Interface (eds A Gomez-Pompa, M Allen, Scott L Fedick, \& Juan J Osornio-Jimenez) Ch. 7, 115-138 (Food Products Press, 2003).

50 Winter, A. et al. Initiation of a stable convective hydroclimatic regime in Central America circa 9000 years BP. Nature Communications 11, 716, doi:10.1038/s41467-020-14490-y (2020).

51 Lachniet, M. S., Asmerom, Y., Bernal, J. P., Polyak, V. J. \& Vazquez-Selem, L. Orbital pacing and ocean circulationinduced collapses of the Mesoamerican monsoon over the past 22,000 y. Proc Natl Acad Sci U S A 110, 9255-9260, doi:10.1073/pnas.1222804110 (2013).

52 Moseley, G. E., Smart, P. L., Richards, D. A. \& Hoffmann, D. L. Speleothem constraints on marine isotope stage (MIS) 5 relative sea levels, Yucatan Peninsula, Mexico. J QUATERNARY SCI 28, 293-300, doi:https://doi.org/10.1002/jqs.2613 (2013).

Taylor, P. M. \& Chafetz, H. S. Floating rafts of calcite crystals in cave pools, central Texas, USA: crystal habit vs. saturation state. J SEDIMENT RES 74, 328-341, doi:https://doi.org/10.1306/111603740328 (2004).

54 Coutino, A., Stastna, M., Kovacs, S. \& Reinhardt, E. Hurricanes Ingrid and Manuel (2013) and their impact on the salinity of the Meteoric Water Mass, Quintana Roo, Mexico. J HYDROL 551, 715-729, doi:https://doi.org/10.1016/j.jhydrol.2017.04.022 (2017).

Kovacs, S. E. et al. Hurricane Ingrid and Tropical Storm Hanna's effects on the salinity of the coastal aquifer, Quintana Roo, Mexico. J HYDROL 551, 703-714, doi:https://doi.org/10.1016/j.jhydrol.2017.02.024 (2017).

Kovacs, S. E. et al. Seasonal trends in calcite-raft precipitation from cenotes Rainbow, Feno and Monkey Dust, Quintana Roo, Mexico: Implications for paleoenvironmental studies. Paleogeogr. Paleoclimatol. Paleoecol. 497, 157-167, doi:https://doi.org/10.1016/j.palaeo.2018.02.014 (2018).

57 Porcelli, D. \& Swarzenski, P. W. The behavior of U-and Th-series nuclides in groundwater. REV MINERAL GEOCHEM 52, 317-361 (2003).

Wendt, K. A. et al. Moisture availability in the southwest United States over the last three glacial-interglacial cycles. Sci. Adv. 4, eaau1375, doi:10.1126/sciadv.aau1375 (2018).

Ritter, S. M. Unravelling the formation of Hells Bells: underwater speleothems from the Yucatán Peninsula in Mexico Ph.D. thesis, Heidelberg University, (2020). 
60 Wefing, A. M. et al. High precision U-series chromatographic $\mathrm{U}$ and Th extraction.
doi:https://doi.org/10.1016/j.chemgeo.2017.10.036 (2017).

Obert, J. C. et al. $230 \mathrm{Th} / \mathrm{U}$ dating of Last Interglacial brain corals from Bonaire (southern Caribbean) using bulk and theca wall material. GEOCHIM COSMOCHIM AC 178, 20-40 (2016).

58162 Gibert, L. et al. Chronology for the Cueva Victoria fossil site (SE Spain): evidence for early Pleistocene Afro-Iberian dispersals. Journal of human evolution 90, 183-197 (2016).

63 Yang, Q. et al. Lead isotope variability in speleothems-A promising new proxy for hydrological change? First results from a stalagmite from western
doi:https://doi.org/10.1016/j.chemgeo.2014.12.028 (2015). University, (2017). by multi-collector inductively coupled plasma mass spectrometry. EARTH PLANET SC LETT 371-372, 82-91, doi:https://doi.org/10.1016/j.epsl.2013.04.006 (2013). 


\section{Supplementary Files}

This is a list of supplementary files associated with this preprint. Click to download.

- supplementSchorndorfetal.pdf 